\title{
PERAN SATUAN BAKTI PEKERJA SOSIAL DALAM MEMBERIKAN LAYANAN PERLINDUNGAN SOSIAL KEPADA ANAK YANG TERKENA DAMPAK PANDEMI COVID-19 DI KOTA BANDUNG
}

\author{
Talenta Veronica \\ Politeknik Kesejahteraan Sosial Bandung, talentaveronica@gmail.com \\ Teta Riasih \\ Politeknik Kesejahteraan Sosial Bandung, tetariasih@yahoo.com \\ Susilawati \\ Politeknik Kesejahteraan Sosial Bandung, susilawati.stks@gmail.com
}

\begin{abstract}
Children are a group that is vulnerable to exposure, also experiencing other problems due to the Covid-19 pandemic. Some of the problems of children affected by the corona virus outbreak, such as child poverty, learning, nutrition, and care and security. Social workers, especially satuan bakti pekerja sosial (sakti peksos) from the Ministry of Social Affairs which are placed in Bandung, are expected to provide protection services for children, especially those affected by Covid-19. This study aims to obtain a deeper picture of the roles of advocates, brokers and educators carried out by Sakti Peksos in Bandung. The researcher used a qualitative approach with descriptive methods with a case study design of the four sakti peksos. The results of this study indicate that children also experience the impact of covid-19, especially in meeting basic needs due to Large-Scale Social Restrictions (PSBB), which are then accessed by social workers. Difficulties of children in meeting their needs are advocated to several related parties, in order to keep children's rights fulfilled. Children's problems are also connected to several source systems that can help overcome children's problems. Sakti Pesos also provides education in the form of information needed by children and families. The role of the educator is not performed optimally by the sakti peksos, due to the lack of understanding of the sakti peksos in providing education by providing online psychosocial support. Sakti peksos also does not understand how to convey the information needed by children and families.
\end{abstract}

Keywords:

Roles, Sakti Peksos, Child, Social Protection, Child Protection

\begin{abstract}
Abstrak
Anak merupakan kelompok yang rentan terpapar, juga mengalami masalah lain akibat pandemik covid-19 Beberapa permasalahan anak yang terkena dampak pandemi covid-19, seperti kemiskinan anak, pembelajaran, gizi, serta pengasuhan dan keamanan. Pekerja sosial, khususnya satuan bakti pekerja sosial (sakti peksos) dari Kementerian Sosial yang
\end{abstract}


ditempatkan antara lain di Kota Bandung, diharapkan memberikan pelayanan perlindungan terhadap anak-anak, terutama yang terdampak covid-19. Penelitian ini bertujuan untuk memperoleh gambaran mengenai peran advokator, broker, dan edukator yang dilakukan oleh sakti peksos di Kota Bandung. Penelitian ini menggunakan metode kualitatif dengan metode deskriptif dengan desain studi kasus terhadap empat sakti peksos. Hasil penelitian ini menunjukkan bahwa anak juga mengalami dampak dari covid-19, khususnya dalam pemenuhan kebutuhan dasar akibat Pembatasan Sosial Berskala Besar (PSBB), yang kemudian diakseskan kepada sakti peksos. Kesulitan anak dalam pemenuhan kebutuhan diadvokasikan kepada beberapa pihak terkait, guna menjaga hak-hak anak dipenuhi. Permasalahan anak juga dihubungkan kepada beberapa sistem sumber yang dapat membantu mengatasi permasalahan anak. Sakti peksos juga memberikan edukasi berupa informasi yang dibutuhkan oleh anak dan keluarga. Peran edukator tidak dilakukan secara optimal oleh sakti peksos, dikarenakan kurangnya pemahaman sakti peksos dalam memberikan edukasi dengan cara pemberian dukungan psiksosoial secara online. Sakti peksos juga kurang memahami cara penyampaian informasi yang dibutuhkan anak dan keluarga secara online. Berdasarkan permasalahan tersebut, maka peneliti merekomendasikan program "Peningkatan Kapasitas Satuan Bakti Pekerja Sosial Jawa Barat dalam Menjalankan Peran Edukator"

Kata Kunci:

Peran, Sakti Peksos, Anak, Perlindungan Anak, Perlindungan Sosial

\section{PENDAHULUAN}

Virus corona merupakan virus yang mewabah hampir di seluruh dunia. World Health Organization(WHO) semenjak Januari 2020 telah menyatakan dunia masuk ke dalam darurat global terkait penyebaran virus corona. Virus corona diketahui masuk ke Indonesia pada pertengahan Februari dan terus mengalami peningkatan. Bahkan pada 20 Mei 2020 total jumlah kasus positif menjadi 18.496 kasus.

Pandemi virus corona tidak hanya menyerang bidang kesehatan masyarakat, namun secara besar-besaran menciptakan disrupi besar-besaran pada bidang politik, sosial kemasyarakatan dan juga ekonomi (ILO, 2020) dalam waktu yang relatif singkat. Pemerintah Indonesia mengupayakan pencegahan dan penanganan resiko dari guncangan dan kerentanan sosial. Adapun langkah yang diambil pemerintah Indonesia guna memutus rantai penyebaran virus corona adalah Pembatasan Sosial Berskala Besar (PSBB).

Pembatasan Sosial Berskala Besar (PSBB) yang dilakukan oleh Indonesia menyebabkan beberapa sektor terganggu dan dibuat lumpuh. Terganggunya sektorsektor ini mengakibatkan timbulnya permasalahan-permasalahan sosial yang dialami oleh masyarakat Indonesia. Pandemi virus corona yang terjadi di Indonesia dapat mempertajam ketimpangan sosial di masyarakat, 
sehingga bagi mereka yang sudah masuk kedalam kelompok marjinal akan mengalami kondisi yang semakin rentan dan tersingkir. Kelompok marjinal yang semakin mengalami kondisi tersingkir adalah mereka kelompok masyarakat yang biasanya menanggung resiko yang tidak proporsional dalam kondisi darurat kesehatan (RCCE dalam Mas'udi dan Winanti, 2020). Kelompok rentan yang dimaksud adalah anak-anak dan lanjut usia, orang dengan disabilitas, kelompok minoritas, etnis atau agama, termasuk masyarakat adat, perempuan, kelompok minoritas gender, serta imigran yang tidak terdokumentasi dan pengungsi, serta masyarakat kurang mampu

Anak-anak menjadi kelompok yang rentan terkena dampak dari pandemi covid-19. Direktur Eksekutif UNICEF sendiri telah menghimbau pemerintah dalam hal ini, bahwa "anak-anak adalah korban yang tidak terlihat" (UNICEF, 2020). Anak menjadi korban tidak terlihat dikarenakan anak rentan terkena dampak, baik dampak dari pandemi covid-19 secara langsung maupun tidak langsung. Dampak langsung dari pandemi covid-19 yakni adanya anak-anak yang terpapar virus corona. Berdasarkan data dari Kementerian Kesehatan hingga pada 30 Mei 2020 mencatat, terdapat 1.851 kasus covid-19 pada anak berusia kurang dari 18 tahun (kompas.com).

Dampak tidak langsung dari pandemi covid-19 bagi anak sendiri, oleh UNICEF (2020) dibagi menjadi empat kategori: (1) kemiskinan anak, (2) pembelajaran, (3) gizi, serta (4) pengasuhan dan keamanan. Dampak tidak langsung ini menyebabkan beberapa anak harus kehilangan orangtua karena covid19. Beberapa orangtua anak harus kehilangan mata pencaharian. Beberapa anak rentan mengalami kekerasan secara fisik dan seksual, serta kesulitan dalam mengakses layanan kesehatan dasar dan gizi. Dampak tidak langsung dari pandemi covid-19 yang dialami anak juga merupakan dampak dari karantina wilayah atau PSBB.

Bappenas (UNICEF, 2020) memproyeksikan bahwa kemungkinan penduduk Indonesia jatuh miskin, naik menjadi 55 persen, dengan sekitar 27 persen calon kelas menengah diperkirakan mengalami ketidakamanan pendapatan yang mengkhawatirkan dan kesulitan memenuhi gizi anak. Permasalahan kemiskinan anak yang dapat mempengaruhi gizi anak. Anak kesulitan dalam pemenuhan gizi, akibat orangtua harus berhenti bekerja yang menyebabkan sulitnya pemenuhan kebutuhan dasar anak.

Kerentanan yang dialami oleh anak juga berdampak pada pengasuhan dan keamanan anak. Kerentanan ini diakibatkan adanya karantina wilayah, yang menyebabkan semua aktifitas dari bekerja, belajar, bermain dan beribadah di sekolah menyebabkan anak rentan mengalami tindak kekerasan. Catatan Tahunan (CATAHU) Komnas Nasional 
Anti Kekerasan terhadap Perempuan (Komnas Perempuan) mencatat selama tahun 2019 terdapat 406.178 kasus kekerasan, yang mana $71 \%$ atau sekitar 9.637 kasus kekerasan dalam rumah tangga atau ranah personal, baik secara fisik, seksual, psikis, hingga ekonomi. Sistem Informasi Online Perlindungan Perempuan dan Anak (SIOPPA, 2020) mencatat rasio anak yang mengalami kekerasan di Jawa Barat terdapat 394 korban baik secacra fisik maupun seksual. SIOPPA bahkan mencatat lokasi tertinggi terjadinya kekerasan adalah di rumah.

Pandemi virus corona menyebabkan beberapa anak mengalami tindak kekerasan fisik dan juga tindak kekerasan seksual yang terjadi di rumah. Kekerasan fisik dapat terjadi dikarenakan orangtua ataupun pengasuh mengalami stress yang luar biasa dalam memenuhi kebutuhan ekonomi dan juga mengasuh anak dalam satu waktu. Orangtua kesulitan untuk mendapatkan pemasukan ditengah pandemi. Orangtua juga dituntut untuk mengajarkan anaknya di rumah. Sehingga rasa stress yang dialami, kemudian dilampiaskan kepada anaknya, dengan memukul, menendang dan menampar anaknya. Kekerasan seksual yang dialami oleh anak dapat terjadi dikarenakan, terlalu seringnya berada di rumah dan dapat terjadi dalam berbagai bentuk kekerasan seksual pada anak. Kekerasan seksual dialami anak, menciptakan rasa tidak aman pada anak, selama berada di rumah. Anak berhak mendapatkan perlindungan dalam bidang sosial dan juga mendapat rasa aman dalam lingkungan sosialnya.

Dampak dari pandemi covid-19 yang dialami oleh anak merupakan perhatian bersama seluruh lapisan masyarakat Indonesia, tidak terkecuali pemerintah. Pemerintah melalui Kemensos RI memberikan himbauan kepada tenaga-tenaga kesejahteraan sosial guna mengatasi dampak dari pandemi, khususnya satuan bakti pekerja sosial (sakti peksos). Sakti peksos secara khusus merespon kasus anak yang terkena dampak dari pandemi covid-19. Pekerja sosial mendukung anak-anak dan keluarga yang rentan saat krisis, sehingga sakti peksos memiliki peranan yang penting pada masa pandemi. Sakti peksos dapat memberikan dukungan terhadap permasalahan-permasalahan dalam perlindungan sosial dan memastikan bahwa anak-anak mendapatkan hak mereka.

Kementerian Sosial melalui Dinas Sosial dan Penanganan Kemiskinan Kota Bandung bersama dengan sakti peksos turut mengambil bagian dalam memberikan perlindungan sosial kepada anak yang terkena dampak pandemi covid19 di Kota Bandung. Adapun upaya-upaya sakti peksos Kota Bandung adalah untuk memberikan rasa aman kepada anak yang menjadi korban tindak kekerasan baik fisik maupun seksual, akibat karantina wilayah atau PSBB yang dilakukan oleh orang terdekat. Sakti peksos juga mengusahakan 
yang terbaik bagi pemenuhan dasar anak, agar gizi anak dapat dipenuhi selama masa pandemi. Upaya-upaya ini dilakukan melalui respon kasus yang merupakan peran dari sakti peksos (Buku Pedoman Satuan Bakti Pekerja Sosial, 2016)

Sakti peksos di di Kota Bandung dituntut untuk membantu mengatasi permasalahan-permasalahan yang dialami oleh anak yang terkena dampak dari pandemi covid-19. Sakti peksos mencatat selama satu tahun terdapat kurang lebih 85 permasalahan anak yang perlu didampingi oleh sakti peksos Kota Bandung. Selama masa pandemi, terdapat beberapa laporan terkait anak yang terkena dampak dari pandemi covid-19 yang memerlukan pertolongan sakti peksos. Anak-anak yang terkena dampak di Kota Bandung sendiri adalah mereka yang orangtuanya tidak bisa bekerja dan tidak bisa keluar mencari nafkah akibat Pembatasan Sosial Berskala Besar (PSBB).

Dampak pandemi covid-19 juga menjadi permasalahan anak yang ditangani oleh sakti peksos. Sakti peksos dalam memberikan perlindungan sosial, menjalankan beberapa peranan dalam menghubungkan, mengadvokasikan, dan memberikan edukasi kepada anak, keluarga dan masyarakat. Peran-peran yang dilakukan oleh sakti peksos sangat penting dalam keberhasilan kebijakankebijakan yang dibuat oleh Kementerian Sosial RI dan juga dalam memberikan perlindungan sosial bagi anak Indonesia.
Sakti peksos pada permasalahan anak korban tindak kekerasan fisik dan kekerasan seksual melakukan advokasi guna memberikan perlindungan di hadapan hukum, pada permasalahan anak terlantar sakti peksos mengadvokasi anak pada dana kedaruratan. Sakti peksos juga menghubungkan anak kepada beberapa sistem sumber yang dapat menyediakan bantuan berupa sembako yang dibutuhkan anak dan kepada sistem sumber yang dapat mengatasi permasalahan anak. Dana kedaruratan merupakan dana yang sebelumnya tidak ada, namun dikarenakan pandemi dan melalui proses advokasi, maka disediakanlah dana kedaruratan. Dana kedaruratan merupakan dana bantuan diluar social safety net reguler, dana tersebut diberikan apabila anak atau keluarga tidak mendapatkan bantuan pemerintah yang sudah ada. Sakti peksos juga memberikan edukasi dengan cara memberikan dukungan psikososial kepada anak dan keluarga yang terkena dampak pandemi covid-19.

Pandemi virus corona memang merupakan fenomena kesehatan, namun dampak dari pandemi covid-19 merupakan fenomena sosial yang dapat meningkatkan kelompok marjinal dan menimbulkan kelompok marjinal baru. Anak-anak pun baik secara langsung maupun tidak langsung terkena dampak dari pandemi covid-19

Permasalahan anak yang diakseskan kepada sakti peksos ditengah pandemi pada akhir Maret sampai dengan Juli 2020, 
dilakukan secara online. Layanan perlindungan yang dilakukan secara online dikarenakan work from home, merupakan suatu tantangan bagi sakti peksos dalam menjalankan perannya, khususnya peran advocator, broker dan educator.

\section{METODE PENELITIAN}

Penelitian ini menggunakan metode kualitatif dengan metode deskriptif dengan desain studi kasus terhadap empat sakti peksos. Lokasi dari penelitian ini adalah Kota Bandung, Jawa Barat. Sumber data penelitian ini berjumlah delapan orang yang terdiri dari empat sakti peksos, dua orangtua klien, satu orang Kasi Rehsos Lansia dan Anak Dinsosnangkis Kota Bandung dan satu orang supervisor sakti peksos Jawa Barat. Data dikumpulkan melalui teknik wawancara mendalam dan studi dokumentasi. Pemeriksaan keabsahan data dilakukan dengan uji kredibilitas dengan cara meningkatkan ketekunan dengan mengamati secara cermat dan berkesinambungan. Triangulasi dengan menggunakan teknik pengumpulan data yang berbeda, dalam penelitian ini menggunakan wawancara dan studi dokumentasi. Triangualasi juga dilakukan dengan mengumpulkan data dari sumber yang berbeda, melalui sakti peksos, supervisor sakti peksos, orangtua klien dan juga klien. Triangulasi juga dilakukan pada waktu yang berbeda guna mendapatkan data jenuh. Menggunakan referensi melalui rekaman ataupun gambar ketika pengumpulan data. Pemeriksaan kebasahan data juga dilakukan dengan pengujian transferability, dimana peneliti membuat laporan secara terperinci, jelas dan sistematis. Pengujian depenability dilakukan dengan audit yang diberikan dosen pembimbing dan pengujian confirmabilty, dimana penelitian disepakati oleh banyak orang. Analisis data kualitatif dilakukan melalui proses reduksi data, penyajian data, dan penarikan kesimpulan.

\section{HASIL PENELITIAN}

\section{Gambaran masalah anak di kota Bandung selama masa pandemi Covid 19}

Anak yang terkena dampak pandemi covid-19 di Kota Bandung memiliki permasalahan yang berbedabeda. Adapun permasalahan anak yang ditangani oleh sakti peksos Kota Bandung adalah permasalahan anak terlantar secara fisik, permasalahan anak korban tindak kekerasan seksual, permasalahan anak korban tindak kekerasan dalam rumah tangga dan anak korban penjambretan. Permasalahan anak terlantar di Kota Bandung disebabkan adanya peraturan Pembatasan Sosial Berskala Besar (PSBB) yang membuat hampir semua orangtua dari anak terlantar harus dirumahkan. Sulitnya orangtua dalam mencari nafkah, membuat orangtua kesulitan dalam memenuhi kebutuhan anak seperti makanan yang menyebab akan mengalami keterlantaran fisik. Anak juga rentan 
menjadi korban tindak kekerasan dalam rumah tangga, baik secara fisik maupun seksual.

Kekerasan fisik yang dialami oleh anak pada masa pandemi terjadi karena alasan sulitnya kondisi perekonomian dari pelaku yang tak lain merupakan ayah tiri dari anak. Kekerasan terjadi dikarenakan orangtua stress, lalu kemudian melampiaskan rasa stress itu kepada anak. Kekerasan yang dilakukan pada anak seperti dipukul, ditendang, ditampar dan lain sebagainya. Bahkan anak korban tindak kekerasan dalam rumah tangga, sampai mengalami sakit yang berkepanjangan, karena terus menjadi pelampiasan amarah dari orangtuanya.

Permasalahan anak yang mengalami kekerasan seksual dilakukan oleh saudara sepupunya, tindakan tersebut dilakukan oleh pelaku, dikarenakan dia terlalu sering menginap di rumah sang paman ketika PSBB diberlakukan. Permasalahan anak lainnya yakni, anak yang menjadi korban penjambretan. Anak yang kesulitan untuk membeli kuota, untuk belajar dan bermain, kemudian menumpang Wi-Fi salah satu hotel. Kemudian pada saat yang bersamaan anak kemudian dijambret dengan ancaman sebuah clurit yang diarahkan pada leheer anak.

Permasalahan anak yang terkena dampak dari pandemi covid-19 ada yang ditangani oleh empat orang satuan bakti pekerja sosial (sakti peksos) di Kota Bandung, untuk kemudian diadvokasikan, dihubungkan pada sistem sumber dan diberikan informasi dan edukasi.

Tabel 1.Ringkasan Permasalahan Anak

\begin{tabular}{|c|c|c|c|c|}
\hline No. & $\begin{array}{l}\text { Permasalahan } \\
\text { Anak }\end{array}$ & $\begin{array}{c}\text { Waktu dan } \\
\text { Lokasi } \\
\text { Permasalahan } \\
\text { Anak Terjadi }\end{array}$ & $\begin{array}{l}\text { Kebutuhan } \\
\text { Anak yang } \\
\text { Sulit } \\
\text { Dipenuhi }\end{array}$ & $\begin{array}{l}\text { Upaya Sakti Peksos } \\
\text { dalam } \\
\text { Menangani } \\
\text { Permasalahan } \\
\text { Anak }\end{array}$ \\
\hline 1 & 2 & 3 & 4 & 5 \\
\hline 1. & $\begin{array}{l}\text { Anak Terlantar } \\
\text { 1) Sakti Peksos } \\
\text { LP }\end{array}$ & $\begin{array}{l}\text { Permasalahan anak } \\
\text { terjadi pada bulan } \\
\text { April di rumah anak, } \\
\text { di Kecamatan } \\
\text { Lengkong. }\end{array}$ & $\begin{array}{l}\text { Kebutuhan akan makanan } \\
\text { sehari-hari, dimana } \\
\text { kondisinya anak dan } \\
\text { ibunya pernah membagi } \\
\text { satu kotak nasi yang } \\
\text { kemudian dibagi tiga } \\
\text { untuk dimakan ketika } \\
\text { berbuka dan sahur. }\end{array}$ & $\begin{array}{l}\text { Sakti peksos selama proses } \\
\text { pendampingan anak terlantar, } \\
\text { mengadvokasikan } \\
\text { kepada dana kedaruratan } \\
\text { dinsos dan menghubungkan } \\
\text { anak kepada sistem-sistem } \\
\text { sumber yang dapat } \\
\text { menyediakan kebutuhan anak } \\
\text { dan memberikan edukasi } \\
\text { kepada orangtua dan anak, } \\
\text { dengan memberikan dukungan } \\
\text { psikososial. }\end{array}$ \\
\hline
\end{tabular}




\begin{tabular}{|c|c|c|c|}
\hline $\begin{array}{l}\text { 2) Sakti Peksos } \\
\text { KD }\end{array}$ & $\begin{array}{l}\text { Permasalahan anak } \\
\text { terjadi pada akhir } \\
\text { bulan Maret di rumah } \\
\text { anak, di Kecamatan } \\
\text { Cibiru. }\end{array}$ & $\begin{array}{l}\text { Kebutuhan akan makan } \\
\text { sehari- hari dan ayahnya } \\
\text { di PHK dan ibunya } \\
\text { sedang sakit. Sehingga } \\
\text { ayahnya tidak bisa } \\
\text { memenuhi kebutuhan } \\
\text { ehari-hari, dikarenakan } \\
\text { tidak ada pemasukan. }\end{array}$ & $\begin{array}{l}\text { Sakti peksos menghubungkan } \\
\text { anak terlantar kepada sistem- } \\
\text { sistem sumber yang dapat } \\
\text { menyediakan bantuan bagi } \\
\text { anak. }\end{array}$ \\
\hline $\begin{array}{l}\text { 3) Sakti Peksos } \\
\text { KD }\end{array}$ & $\begin{array}{l}\text { Permasalahan anak } \\
\text { terjadi pada akhir } \\
\text { bulan Maret di rumah } \\
\text { anak, di Kecamatan } \\
\text { Babakan Ciparay. }\end{array}$ & $\begin{array}{lr}\text { Kebutuhan } & \text { akan } \\
\text { permakanan anak tinggal } \\
\text { bersama neneknya, } \\
\text { sementara ayahnya } \\
\text { dipenjara dan ibunya } \\
\text { sudah sejak lama } \\
\text { meninggalkan anak dan } \\
\text { suaminya. }\end{array}$ & \\
\hline $\begin{array}{l}\text { Anak Korban } \\
\text { Kekerasan Fisik }\end{array}$ & $\begin{array}{l}\text { Permasalahan anak } \\
\text { terjadi antara bulan } \\
\text { April atau Mei di } \\
\text { rumah anak, di } \\
\text { Kecamatan } \\
\text { Cicaheum. }\end{array}$ & $\begin{array}{l}\text { Anak menjadi korban } \\
\text { tindak kekerasan seksual } \\
\text { oleh orang terdekat anak. } \\
\text { Sementara orangtua anak } \\
\text { tidak mengetahui cara } \\
\text { melaporkan } \\
\text { permasalahan anak. } \\
\text { Kebutuhan anak yang } \\
\text { diperlukan setelah } \\
\text { menjadi korban tindak } \\
\text { kekerasan seksual adalah } \\
\text { kebutuhan akan } \\
\text { pendampingan pada } \\
\text { proses hukum dan dalam } \\
\text { mengatasi permasalahan } \\
\text { psikologis anak akibat } \\
\text { tindak kekerasan } \\
\text { seksual. }\end{array}$ & $\begin{array}{l}\text { Sakti peksos memberikan } \\
\text { edukasi kepada orangtua anak } \\
\text { terkait cara melaporkan } \\
\text { permasalahan anak kepada } \\
\text { pihak kepolisian. Sakti peksos } \\
\text { juga memberikan } \\
\text { pendampingan anak selama } \\
\text { proses hukum, dikarenakan } \\
\text { anak merupakan korban. Sakti } \\
\text { peksos juga menghubungkan } \\
\text { anak kepada psikolog yang } \\
\text { berada di Pusat Pelayanan } \\
\text { Terpadu Pemberdayaan } \\
\text { Perempuan dan Anak } \\
\text { (P2TP2A) untuk kemudian } \\
\text { mendapatkan pelayanan terkait } \\
\text { psikologis anak dan } \\
\text { memberikan edukasi kepada } \\
\text { orangtua dan anak. }\end{array}$ \\
\hline \begin{tabular}{l|} 
Anak Korban \\
Kekerasan \\
Seksual \\
1) Melalui Jalur \\
Hukum
\end{tabular} & $\begin{array}{lr}\text { Permasalahan anak } \\
\text { terjadi r pada } \\
\text { pertengahan bulan } \\
\text { April atau awal bulan } \\
\text { Mei di rumah } \\
\text { kontrakan anak di } \\
\text { Kecamatan Kebon } \\
\text { Pisang. }\end{array}$ & $\begin{array}{l}\text { Anak menjadi } \\
\text { pelampiasan kemarahan } \\
\text { sehingga mendapatkan } \\
\text { tindak kekerasan oleh } \\
\text { ayahnya. Kekerasan } \\
\text { terjadi dikarenakan rasa } \\
\text { stress anak dan stress. } \\
\text { Anak membutuhkan } \\
\text { perlindungan dimuka } \\
\text { hukum, dikarenakan anak } \\
\text { merupakan korban dan } \\
\text { mendapat pelayanan }\end{array}$ & $\begin{array}{l}\text { Sakti peksos memberikan } \\
\text { pendampingan selama proses } \\
\text { hukum, dikarenakan anak } \\
\text { menjadi korban dan } \\
\text { permasalahan kekerasan dalam } \\
\text { rumah tangga sudah masuk ke } \\
\text { jalur hukum. Anak juga } \\
\text { diadvokasikan } \\
\text { dihubungkan pada layanan } \\
\text { kesehatan dikarenakan anak } \\
\text { sakit. Sakti peksos juga } \\
\text { memberikan edukasi kepada } \\
\text { keluarga besar mengenai pola }\end{array}$ \\
\hline
\end{tabular}




\begin{tabular}{|c|c|c|c|}
\hline & & $\begin{array}{l}\text { kesehatan, } \\
\text { dikarenakan } \\
\text { kekerasan fisik } \\
\text { meninggalkan } \\
\text { fersebut } \\
\text { fisik anak }\end{array}$ & $\begin{array}{l}\text { asuh, untuk kemudian anak } \\
\text { dirawat oleh keluarga } \\
\text { besar untuk sementara waktu. }\end{array}$ \\
\hline $\begin{array}{l}\text { 2) Tidak } \\
\text { Melalui } \\
\text { Jalur } \\
\text { Hukum }\end{array}$ & $\begin{array}{l}\text { Permasalahan terjadi } \\
\text { pada bulan April di } \\
\text { rumah anak di } \\
\text { Kecamatan Astana } \\
\text { Anyar. }\end{array}$ & 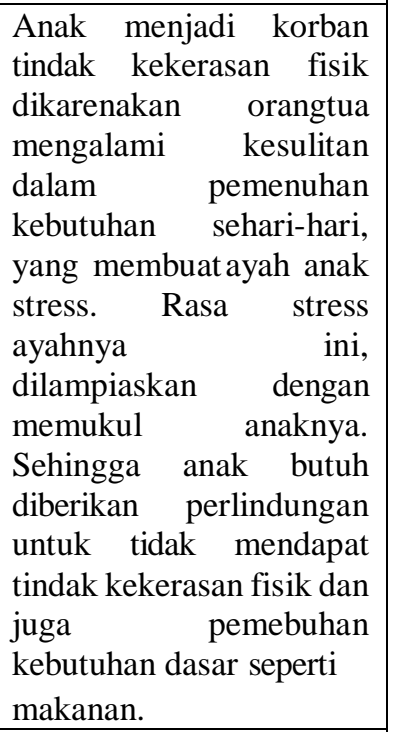 & $\begin{array}{l}\text { Sakti peksos mengupayakan } \\
\text { utnuk mengadvokasikan anak, } \\
\text { dengan membuat surat } \\
\text { perjanjian kepada pihak } \\
\text { pemerintah kewilayahan untuk } \\
\text { tidak melakukan tindak } \\
\text { kekerasan pada anak. Sakti } \\
\text { peksos juga menghubungkan } \\
\text { anak kepada beberapa sistem } \\
\text { sumber seperti yayasan yang } \\
\text { menyediakan kebutuhan dasar } \\
\text { dan bisa diakseskan kepada } \\
\text { anak. sakti peksos memberikan } \\
\text { edukasi kepada orangtua dan } \\
\text { anak melalui dukungan } \\
\text { psikososial. }\end{array}$ \\
\hline $\begin{array}{l}\text { Anak } \\
\text { Korban } \\
\text { Penjambretan }\end{array}$ & $\begin{array}{l}\text { Permasalahan anak } \\
\text { terjadi pada bulan } \\
\text { akhir bulan April di } \\
\text { depan hotel x di } \\
\text { Kecamatan } \\
\text { Bojongloa Kaler. }\end{array}$ & $\begin{array}{lr}\text { Kebutuhan anak } & \text { akan } \\
\text { kuota untuk } & \text { melakukan } \\
\text { belajar dan } & \text { bermain } \\
\text { secara online. } & \text { Setelah } \\
\text { menjadi } & \text { korban } \\
\text { penjambretan, } & \text { yang } \\
\text { menjadi kebutuhan anak } \\
\text { yakni pendampingan } \\
\text { proses BAP } & \text { dan } \\
\text { kebutuhan } & \text { akan } \\
\text { mengatasi } & \text { perasaan } \\
\text { trauma } & \\
\text { anak. }\end{array}$ & $\begin{array}{ll}\text { Sakti peksos mendampingi } \\
\text { anak pada proses } \\
\text { pAP. Sakti } \\
\text { peksos juga memberikan } \\
\text { edukasi kepada anak dan } \\
\text { keluarga. } & \end{array}$ \\
\hline
\end{tabular}

Sumber : Hasil Penelitian Tahun 2020

\section{PEMBAHASAN}

Berdasarkan hasil penelitian yang diperoleh melalui wawancara dan studi dokumentasi, diketahui bahwa satuan bakti pekerja sosial (sakti peksos) menjalankan peran-peran pekerja sosial yang tiga diantaranya dipaparkan oleh Zastrow (2017:67) yakni peran sebagai advocate, broker dan educator. Webb (2011) juga menuliskan ketiga peran tersebut sebagai peran pekerja sosial yang bekerja dengan anak, yakni peran advocate, broker dan educator. Berikut analisis dari hasil penelitian yang akan diuraikan mengenai bahasan gambaran permasalahan anak, peran advokat sakti 
peksos, peran broker sakti peksos dan peran edukator sakti peksos:

\section{Gambaran Permasalahan Anak}

Hasil penelitian ditemukan beberapa permasalahan yang dialami oleh anak. Permasalahan yang dialami anak merupakan dampak dari pandemi covid-19 secara tidak langsung, dimana anak bukan merupakan anak yang terpapar langsung oleh virus corona. Dampak tidak langsung ini diuraikan UNICEF (2020) dalam empat kategori: (1) kemiskinan anak, (2) pembelajaran, (3) gizi, serta (4) pengasuhan dan keamanan. Berdasarkan hasil wawancara, diketahui bahwa permasalahan anak yang terkena dampak dari pandemi covid-19 meliputi permasalahan anak terlantar.

Permasalahan anak terlantar yang merupakan anak yang terkena dampak dari pandemi covid-19 ini secara tidak langsung kebutuhan akan pemenuhan kebutuhannya tidak memadai. Huttman dalam Muhidin dan dalam Abu Huraerah (2012: 38-39) memaparkan ada sepuluh kebutuhan anak yang harus terpenuhi, salah satunya adalah pemenuhan kebutuhan makanan. Sulitnya pemenuhan kebutuhan permakanan dapat menyebabkan anak kekurangan gizi dan membuat hak anak untuk dapat hidup, tumbuh, berkembang tidak terpenuhi secara optimal.

Permasalahan anak terlantar, kemudian diakseskan kepada sakti peksos. Sakti peksos menangani tiga permasalahan anak terlantar dan kemudian salah satunya merupakan anak korban tindak kekerasan dalam rumah tangga yang juga kesulitan dalam pemenuhan kebutuhan makanan. Anak yang terkena dampak dari pandemi covid-19 juga terkait dengan pengasuhan dan keamanan. Pengasuhan dan keamanan menjadi salah satu dampak pandemi covid-19 bagi anak, dikarenakan PSBB membuat anak juga harus bermain dan belajar di rumah. Anak juga rentan menjadi korban tindak kekerasan dalam rumah tangga, baik secara fisik maupun seksual.

Sakti peksos menangani dua permasalahan anak yang menjadi korban tindak kekerasan dalam rumah tangga secara fisik. Permasalahan anak yang menjadi korban tindak kekerasan dalam rumah tangga secara fisik, kehilangan kebutuhan anak akan pemeliharaan, perawatan dan perlindungan yang disampaikan oleh Huttman dalam Muhidin dalam Huraerah. Diperlakukan salah secara fisik dapat menghambat pertumbuhan dan kesejahteraan anak secara fisik, intelektual, emosional dan sosisal anak seperti yang dipaparkan oleh Soetarso dalam Huraerah (2012). Permasalahan anak korban tindak kekerasan secara fisik merupakan pelanggaran terhadap hak perlindungan anak yang tercantum dalam Konvensi Hak Anak (KHA). Terlepas dari apapun alasan dari pelaku kekerasan, tindak kekerasan pada anak tidak dapat dibenarkan, sehingga diakseskan kepada sakti peksos.

Dampak pengasuhan dan keamanan lainnya yang ditangani oleh sakti peksos, 
terkait dengan permasalahan anak yang mengalami kekerasan seksual. Rumah menjadi tidak aman bagi anak, walaupun waktu pertama kali berhubungan seksual, anak mengira itu sebagai bentuk kasih sayang dari saudaranya. Kebutuhan anak yang tidak terpenuhi pada permasalahan anak ini merupakan kebutuhan akan pemeliharaan, perawatan dan perlindungan. Adapun hak anak yang dilanggar yakni hak anak untuk mendapat perlindungan dari perlakuan salah seperti pelecehan atau perbuatan yang tidak senonoh.

Permasalahan anak yang juga diakseskan kepada sakti peksos, yakni permasalahan anak yang menjadi korban penjambretan. Anak yang kesulitan untuk membeli kuota, untuk belajar dan bermain, kemudian menumpang Wi-Fi salah satu hotel. Kemudian pada saat yang bersamaan anak kemudian dijambret dengan ancaman sebuah clurit yang diarahkan pada leheer anak. Tindakan penjambretan tersebut membuat anak mengalami keterkejutan dan juga emosi yang tidak stabil, masih ada ketakutan pada anak atas kejadian yang dialami. Permasalahan lainnya, mengenai cara anak kedepannya dalam belajar, dikarenakan handphone yang dimilikinya telah diambil penjambret. Kebutuhan anak korban penjambretan mengenai stabilitas emosional yang disampaikan Huttman dalam Muhidin dalam Huraerah. Hak anak untuk memperoleh pendidikan dan bermain, kemudian perlu dioptimalkan.
Permasalahan-permasalahan anak yang terkena dampak dari pandemi covid19 kemudian diakseskan kepada sakti peksos untuk mendapatkan perlindungan sosial. Perlindungan sosial bagi anak diharapkan dapat melidungi dan menangani resiko kerentanan yang dialami oleh anak. Anak yang terkena dampak dari pandemi covid-19 berhak mendapatkan perlindungan baik secara yuridis maupun non-yuridis.

Berrdasarkan hasil penelitian mengenai penanganan-penanganan yang dilakukan oleh sakti peksos, dapat diketahui bahwa sakti peksos melakukan advokasi kepada Kementerian Sosial untuk dana kedaruratan yang akan diberikan melalui Dinas Sosial-Dinas Sosial daerah. Advokasi dilakukan agar anak dan keluarga rentan tetap mendapatkan bantuan dan perlindungan sosial guna mengatasi kerentanan yang dialami oleh anak dan keluarga rentan. Penanganan pada permasalahan anak terlantar ini kemudian juga menjadi pencegahan terkait permasalahan yang mungkin dapat dialami oleh anak terlantar lainnya untuk memperoleh bantuan. Kementerian Sosial tetap mengusahakan agar gizi anak tetap dapat terpenuhi selama masa pandemi.

Sakti peksos pada penangananpenanganan permasalahan anak terlantar lebih banyak menjalankan peran broker dengan menghubungkan anak kepada sistem sumber yang dapat memberikan bantuan yang dibutuhkan oleh anak dan 
keluarga. Penanganan terhadap anak korban tindak kekerasan seksual lebih banyak dilakukan dengan memberikan edukasi terkait dengan cara melaporkan permasalahan anak kepada pihak berwajib dan mendampingi anak selama proses hukum berlangsung. Penanganan terhadap permasalahan anak korban tindak kekerasan dalam rumah tangga lebih banyak dilakukan dengan memberikan pendampingan kepada anak selama proses hukum dan mengakseskan anak kepada beberapa sistem sumber yang dibutuhkan oleh anak.

\section{Peran Advokat Satuan Bakti Pekerja Sosial}

Berdasarkan hasil penelitian, diketahui bahwa satuan bakti pekerja sosial (sakti peksos) menjalankan peran advokat. Menurut Zastrow (2017) Advokat merupakan peran aktif dan terarah dimana pekerja sosial mengadvokasikan klien atau untuk masyarakat-masyarakat yang membutuhkan bantuan dan institusi yang menyediakan layanan yang dibutuhkan masyarakat. Menurut Webb (2011) advokat yang dilakukan pekerja sosial guna membantu anak-anak dalam memperoleh haknya, baik berupa sumber daya, pelayanan atau aktif dalam mendukung kebijakan program yang berhubungan dengan anak. Sakti peksos dalam menjalankan peran advokasi dilakukan pada permasalahan anak terlantar, korban tindak kekerasan seksual, anak korban tindak kekerasan dalam rumah tangga dan anak korban penjambretan. Tidak semua sakti peksos menjalankan peran advokasi, salah satu sakti peksos tidak menjalankan peran advokasi.

Sakti peksos dalam menjalankan peran advokasi pada permasalahan anak terlantar mengadvokasikan permasalahan anak pada institusi yang dibutuhkan salah satunya adalah Kementerian Sosial yang melalui Dinas-Dinas Sosial di seluruh Indonesia, salah satunya Kota Bandung menyediakan dana kedaruratan. Dana kedaruratan ini digunakan untuk mereka yang tidak mendapatkan bantuan-bantuan yang sudah tersedia sebelumnya. Pengadvokasian pada permasalahan anak terlantar merupakan bentuk perlindungan terhadap hak anak untuk kelangsungan hidup anak dan untuk tidak mengalami penelantaran. Pengadvokasian pada permasalahan anak terlantar dilakukan setelah beberapa hari permasalahan ditangani oleh sakti peksos, dikarenakan sakti peksos membantu menyiapkan syarat-syarat yang dibutuhkan untuk kemudian diajukan kepada pihak Kemensos. Sebelumnya, dana kedaruratan merupakan dana yang sudah diadvokasikan terlebih dahulu oleh saktisakti di Indonesia untuk membantu permasalahan-permasalahan bagi mereka yang tidak mendapatkan bantuan.

\begin{tabular}{ccrr} 
Sakti & peksos & dalam \\
mengadvokasikan & anak & \multicolumn{2}{r}{ kebanyakan } \\
dilakukan di & Dinas & Sosial & dan
\end{tabular}


Penanggulangan Kemiskinan Kota Bandung. Pengadvokasian dilakukan dalam rangka berbicara atas nama klien kepada pihak Dinsosnangkis. Pegadvokasian kemudian perlu dilakukan karena kondisi anak yang benar-benar dalam kondisi terlantar dan sudah beberapa hari kesulitan untuk makan. Sakti peksos dalam mengadvokasikan anak melalui beberapa tahapan seperti identifikasi masalah yang dilakukan dengan menghubungi ibu dari anak terlantar dan kemudian merumuskan solusi yang memungkinkan, salah satunya pengadvokasian pada dana kedaruratan. Sakti peksos kemudian mengadvokasikan anak kepada pihak Dinsosnangkis Kota Bandung setelah lengkap dengan persyaratan yang dibutuhkan.

Sakti peksos dalam menjalankan peran advokasi pada permasalahan anak korban penjambretan mengadvokasikan permasalahan anak dengan memberikan pendampingan kepada anak ketika proses pembuatan BAP. Anak berhak memperoleh bantuan hukum atau lainnya, sehingga anak berhak mendapatkan bimbingan ataupun pendampingan dari sakti peksos. Sakti peksos dalam melaksanakan peran advokasi pada permasalahan anak korban penjambretan banyak dilakukan di kantor polisi. Permasalahan anak korban penjambretan yang ditangani sakti peksos merupakan permasalahan yang diakseskan oleh polisi kepada sakti peskos. Sehingga pada prosesnnya, sakti peksos banyak bekerja sama dengan polisi dalam mengadvokasikan permasalahan anak.

Sakti peksos pada permasalahan anak korban penjambretan perlu melakukan pengadvokasian karena hak anak untuk mendapatkan perlindungan secara yuridis, dimana anak berhak memperoleh rasa aman dan perlindungan dihadapan hukum. Sakti peksos juga mengadvokasikan permasalahan anak korban tindak kekerasan seksual. Pengadvokasian dilakukan oleh sakti peksos bersama dengan ayahnya dengan cara melaporkan tersangka yang melakukan kekerasan seksual pada anak usia tujuh tahun, dimana tersangka sudah tidak termasuk pada usia anak. Pengadvokasian dilakukan agar anak mendapatkan keadilan dan rasa aman kedepannya.

Sakti peksos dalam mengadovkasikan permasalahan anak memberikan perlindungan pada anak secara yuridis, dimana anak diberikan perlindungan pada proses hukum, dikarenakan anak merupakan korban dari tindak kekerasan seksual tersebut. Sakti peksos dalam mengadvokasikan permasalahan anak korban tindak kekerasan seksual banyak bekerja sama dengan pihak kepolisian. Advokasi yang dilakukan oleh sakti peksos pada penanganan anak korban tindak kekerasan seksual, dilakukan selama proses pendampingan. Sakti peksos sebelum akhirnya mendavokasikan anak, mengidentifikasi terlebih dahulu 
mengenai permasalahan yang dialami anak. Setelah sakti peksos mengidenfikasi permasalahan anak, sakti peksos merumuskan solusi dan melaksanakan pengadvokasian yang dibutuhkan oleh anak.

Sakti peksos dalam menjalankan peran advokasi pada permasalahan anak korban tindak kekerasan dalam rumah tangga melakukan dua pengadvokasian, pengadvokasian pada lingkungan sosial dan juga melalui jalur hukum. Perlindungan anak secara yuridis pada permasalahan anak korban tindak kekerasan dalam rumah tangga yang diberikan oleh sakti peksos adalah dengan mendampingi anak yang sebagai korban pada proses hukum. Perlindungan anak secara non-yuridis diberikan oleh sakti peksos dalam perlindungan anak dalam bidang sosial dan kesehatan. Perlindungan non-yuridis dilakukan karena anak sampai mengalami lebam dan bengkak serta demam akibat dipukuli, ditendang dan ditampar ayah tiri anak. Sakti peksos menjalankan peran advokasi pada permasalahan anak korban tindak kekerasan dalam rumah tangga, setelah permasalahan anak diakseskan kepada sakti peksos. Sakti peksos dalam menjalankan peran sebagai advokat pada permasalahan anak korban tindak kekerasan dalam rumah tangga banyak melibatkan pihak kepolisian. Anak korban tindak kekerasan dalam rumah tangga perlu diadvokasikan karena anak berhak mendapatkan perlidungan dari tindak kekerasan dan penganiayaan.

Sakti peksos dalam

mengadvokasikan anak korban tindak kekerasan seksual melalui jalur hukum, melalui identifikasi masalah telebih dahulu. Setelah sakti peksos mengidentifikasi masalah, sakti peksos merumuskan solusi-solusi yang dibutuhkan oleh anak. Sakti pekos kemudian mendiskusikan solusi-solusi tersebut. Setelah itu barulah anak mendapatkan layanan yang dibutuhkan.

Permasalahan anak korban tindak kekerasan yang diadvokasi melalui jalur masyarakat, dilakukan karena adanya permohonan ibu dari anak, untuk tidak mempindakan ayahnya. Sehingga sakti peksos perlu merumuskan solusi-solusi bagi permasalahan anak tersebut agar tidak mengalami kejadian yang sama. Sehingga sakti peksos pada permasalahan tersebut, mengadvokasikan pada pihak kewilayahan tempat anak tinggal. Sakti peksos dalam melakukan advokasi pada pihal kewilayah, dilakukan seminggu setelah permasalahan ditangani oleh sakti peksos. Pengadvokasian tersebut perlu dilakukan karena tidak terpenuhinya hak anak untuk mendapat perlindungan dari sasaran penganiayaan dan kekerasan. Sakti peksos pada permasalahan anak yang menjadi korban tindak kekerasan dalam rumah tangga yang diakseskan kepada masyarakat, dilakukan ketika berada di rumah, karena pada saat itu sakti peksos sedang bekerja dari rumah. Setelah semua 
pihak kewilayahan dapat ditemui, barulah sakti peksos melakukannya di Kelurahan tempat anak tinggal.

Salah satu sakti peksos dalam menangani permasalahan anak terlantar tidak melakukan pengadvokasian, dikarenakan kurang memahami pengadvokasian permasalahan anak terlantar. Sakti peksos dalam mengdavokasikan anak mengalami beberapa hambatan seperti sulitnya membuat janji dengan pihak-pihak yang dilibatkan dalam pengadvokasian, sulitnya melakukan advokasi secara daring, perijinan penanganan secara langsung atau SOP (Standard Operational Procedure) dan kurangnya skill. Berdasarkan hasil penelitian, permasalahan yang dialami oleh sakti peksos dalam menjalankan peran advokat yakni latar belakang pendidikan sakti peksos tidak semuanya merupakan lulusan pekerjaan sosial atau kesejahteraan sosial dan pelatihanpelatihan mengenai advokasi yang diikuti oleh sakti peksos masih terhitung sedikit.

Sakti peksos pada pelaksanaan peran advokat pada permasalahan anak terlantar, anak korban penjambretan dan anak korban tindak kekerasan dalam rumah tangga berjalan dengan cukup baik, hal ini dikarenakan sakti peksos telah melakukan tahap-tahap pengadvokasian yang disampaikan oleh Fahrudin (2010) yakni tahap identifikasi masalah, perumusan solusi, membangun kemauan politik, melaksanakan kebijakan dan evaluasi. Sakti peksos mengidentifikasi masalah- masalah dan kebutuhan-kebutuhan anak yang kemudian dirumuskan solusi-solusi yang memungkinkan untuk dilaksanakan. Setelah itu, sakti peksos membangun kemauan politik, kepada pihak Kementerian Sosial Republik Indonesia.

Sakti peksos juga telah melaksanakan pendampingan selama proses hukum dengan baik. Namun salah satu sakti peksos yang menjalankan peran advokat pada permasalahan anak korban tindak kekerasan seksual, masih banyak belajar dengan sakti peksos senior. Sakti peksos terkadang masih dijelaskan mengenai keterampilan-keterampilan dalam pengadvokasian dan kode etik pekerja sosial.

\section{Peran Broker Satuan Bakti Pekerja Sosial}

Berdasarkan hasil penelitian, diketahui bahwa satuan bakti pekerja sosial (sakti peksos) menjalankan peran broker. Menurut Zastrow (2017) peran pekerja sosial sebagai borker merupakan peran sebagai seorang pernghubung, dimana pekerja sosial menghubungkan individu-individu dan kelompok yang membutuhkan bantuan (dan tidak mengetahui informasi) dengan pelayananpelayanan di komunitas. Menurut Webb (2011) broker merupakan peran pekerja sosial dalam menghubungkan anak dengan sistem-sistem sumber serta pelayanan yang dibutuhkan untuk memecahkan masalah yang dihadapi anak.

Sakti peksos dalam menjalankan peran broker dilakukan pada 
permasalahan anak terlantar, korban tindak kekerasan seksual, anak korban tindak kekerasan dalam rumah tangga dan anak korban penjambretan. Tidak semua permasalahan dihubungkan kepada sistem sumber, sakah satu permasalahan yang tidak dihubungkan kepada sistem sumber ialah permasalahan anak korban penjambretan.

Sakti peksos dalam menjalankan peran broker pada permasalahan anak terlantar melakukannya pada saat permasalahan anak diakseskan kepada sakti peksos, permasalahan anak terlantar yang ditangani untuk kemudian dihubungkan pada sistem sumber, mencakup tiga permasalahan dan satu permasalahan anak korban tindak kekerasan yang juga sulit memenuhi kebutuhan makanan. Permasalahan anak terlantar yang ditangani oleh sakti peksos umumnya terkait dengan penelantaran fisik, dimana sulitnya memenuhi kebutuhan makanan dan gizi anak. Permasalahan anak terlantar ini ditangani oleh tiga peksos yang berbeda untuk kemudian dihubungkan pada sistem sumber. Dua sakti peksos menghubungkan anak pada sistem sumber dilakukan dari rumah, karena selama pandemi sakti peksos juga mengikuti aturan bekerja dari rumah. Salah sakti peksos bahkan langsung menghubungkan anak kepada sistem sumber pada saat selesai melakukan asesmen by phone. Sakti peksos menghubungkan anak kepada jejaring- jejaring dari organisasi luar yang memiliki keperdulian terhadap permasalahan anak.

Permasalahan anak yang sulit mengenai permakanan dan juga kekerasan dalam rumah tangga, juga dihubungkan pada sistem sumber oleh salah satu sakti peksos. Sakti peksos dalam menjalankan peran broker, langsung mendatangi salah satu yayasan yang dapat memberikan bantuan pada anak. Sakti peksos yang langsung pergi ke sistem sumber, mengikuti SOP yang ada dan mengikuti protokol kesehatan yang ada. Sakti peksos pada permaslaahan anak terlantar, perlu melakukan peran broker demi kepentingan yang terbaik bagi anak dan guna memenuhi kebutuhan anak akan pemenuhan kebutuhan makanan anak. Adapun sakti peksos dalam menghubungkan anak dengan sistem sumber, dilihat berdasarkan hasil asesmen. Setelah itu sakti peksos mencoba menghubungi sistem sumber yang dapat menyediakan layanan ataupun bantuan bagi anak. Sakti peksos dalam mencari ssitem sumber, mencoba dari berbagai sumber yang ada, mulai dari yayasan, pemeritahan, organisasi dan jejaring personal.

Sakti peksos dalam menjalankan peran broker pada permasalahan anak korban kekerasan seksual menjalankan perannya selama proses pendampingan anak. Sakti peksos dalam menjalankan peran broker lebih banyak menghubungkan anak di Pusat Pelayanan Terpadu Pemberdayaan Perempuan dan 
Anak (P2TP2A) Kota Bandung. Anak korban kekerasan seksual dihubungkan kepada psikolog yang berada di P2TPA. Anak dihubungkan kepada psikolog, dikarenakan kondisi emosi anak yang tidak stabil dan diperlakukan salah secara seksual dapat menghambat pertumbuhan dan kesejahteraan fisik, intelektual, emosional dan sosial anak (Soetarso dalam Huraerah, 2012). Sakti peksos menjalankan peran sebagai broker pada permasalahan anak korban tindak kekerasan seksual dikarenakan orangtua anak yang minim akan informasi mengenai sistem sumber yang dapat diakses oleh anak dan keluarga.

Sakti peksos dalam menjalankan peran broker pada permasalahan anak korban kekerasan dalam rumah tangga, menjalankan perannya ketika permasalahan anak diakseskan kepada sakti peksos. Sakti peksos menghubungkan anak pada sistem sumber dengan bekerja semantara waktu dengan pihak P2TP2A yang mengakseskan permasalahan anak untuk ditangani sakti peksos dan di UPT Puskesos (Unit Pelayanan Teknis Pusat Kesejahteraan Sosial) di Dinas Sosial dan Penanggulangan Kemiskinan Kota Bandung. Anak sementara waktu sambil menunggu proses hukum, diamankan di UPT Puskesos, sembari dilakukannya asesmen dan intervensi lebih lanjut. Anak juga tetap dihubungkan pada layanan kesehatan Pusat Kesehatan Masyarakat (Puskesmas) terdekat di Dinsosnangkis
Kota Bandung, agar anak dapat segera pulih. Hal ini merupakan upaya yang dilakukan sakti peksos untuk memberikan perlindungan bagi anak yang menjadi korban tindak kekerasan dalam rumah tangga.

Sakti peksos pada permasalahan anak korban penjambretan tidak melakukan peran sebagai broker dikarenakan sakti peksos lebih menekankan pada dukungan psikososial. Sakti peksos dalam menjalankan peran sebagai broker mengalami hambatan yang pada umumnya sulit mencari sistem sumber, melaksanakan beberapa hal termasuk menghubungkan anak kepada sistem sumber secara online dan merasakan hambatan pada ruang gerak yang terbatas.

Berdasarkan hasil penelitian, dapat diketahui bahwa sakti peksos menjalankan peran broker dengan baik. Adapun hambatan-hambatan dari pelaksanaan peran broker terletak pada sistem-sistem sumber kemasyarakatan swasta yang merupakan organisasi-organisasi sosial yang juga pada masa pandemi kesulitan dalam menyediakan bantuan ataupun kebutuhan yang dicari. Namun, sakti peksos tetap mengusahakan sistem-sistem sumber tersebut, hal ini terlihat dari adanya yayasan-yayasan, organisasi dan kelompok sosial yang diakseskan kepada anak. 


\section{Peran Edukator Satuan Bakti Pekerja Sosial}

Berdasarkan hasil penelitian, diketahui bahwa satuan bakti pekerja sosial (sakti peksos) menjalankan peran edukator. Peran edukator mencakup pemberian informasi kepada klien dan memberikan keterampilan adaptif. Pekerja sosial harus terlebih dahulu memiliki pengetahuan yang akan diberikan. Selain itu, pekerja sosial mampu mengkomunikasikan segala informasi dengan baik, sehingga dapat dipahami oleh klien. pekerja sosial memberikan informasi tentang sumber-sumber yang dibutuhkan oleh anak dan keluarga dan memberikan pengetahuan kepada anak dan keluarga sesuai dengan kebutuhan anak dan keluarga. Pekerja sosial juga memperkuat kemampuan yang dimiliki oleh anak.

Sakti peksos dalam menjalankan peran edukator pada permasalahan anak terlantar dilakukan pada saat seminggu menangani permasalahan anak. Pemberian edukasi dan informasi yang diberikan oleh sakti peksos, dilakukan secara langsung pada orangtua anak. Sakti peksos pada permasalahan anak terlantar tetap memberikan informasi yang dibutuhkan oleh anak dan orangtua anak selama pendampingan yang dilakukan oleh sakti peksos. Sakti peksos juga beberapa kali memberikan edukasi ketika sedang bekerja dari rumah, pemberian edukasi ini dilakukan by phone dengan menggunakan WhatsApp
Sakti peksos memberikan edukasi dikarenakan ibu dari anak terlantar kekurangan informasi mengenai bantuan yang diakses. Sakti peksos selama masa pandemi tidak bisa melakukan edukasi melalui TEPAK (Temu dan Penguatan Keluarga) maka sakti peksos memberikan dukungan psikososial kepada orangtua anak, agar tetap mampu mengatasi situasi pandemi yang menyebabkan sulitnya mencari nafkah dan pemenuhan kebutuhan sehari-hari. Sakti peksos dalam memberikan edukasi dilakukan dengan komunikasi seperti biasa, dikarenakan pada masa pandemi adanya pembatasan kegiatan yang melibatkan banyak masa.

Sakti peksos dalam menjalankan peran edukator pada permasalahan anak korban penjambretan menjalankan peran edukator pada pertama kali permasalahan anak diakseskan kepada sakti peksos melalui polisi. Sehingga sakti peksos memberikan edukasi ketika berada di kantor polisi. Sakti peksos juga memberikan edukasi kepada anak dan keluarga selama proses pendampingan. Sakti peksos terkadang melakukan peran sebagai edukator pada permasalahan anak korban penjambretan ketika visit ke rumah anak dan ketika sakti peksos sedang bekerja dari rumah. Pemberian edukasi yang dilakukan oleh sakti peksos sangat diperlukan karena barang yang dijambret adalah handphone anak, yang pada masa pandemi dan belajar dari rumah, menjadikan handphone sebagai suatu kebutuhan dalam pembinaan kemampuan 
intelektual anak. Merupakan hak anak untuk belajar dan bermain, padahal anak menumpang Wi-Fi hotel untuk belajar sekaligus bermain. Sehingga pemberian edukasi kepada orangtua anak mengenai waktu tumbuh kembang anak dan mengenai kebutuhan anak, agar kiranya secara besama-sama dipikirkan mengenai solusi anak.

Sakti peksos juga memberikan edukasi kepada anak, mengenai cara yang aman untuk mendapatkan Wi-Fi. Sakti peksos juga memberikan edukasi mengenai bahayanya jalanan, dikarenakan anak menggunakan Wi-Fi hotel yang berada di pinggir jalan raya. Sakti peksos memberikan edukasi kepada anak dengan cara membuat logika berpikir mengenai mana yang baik dan tidak, dan mengenai mana yang berbahaya dan tidak.

Sakti peksos dalam menjalankan peran edukator pada permasalahan anak korban tindak kekerasan seksual dilakukan pada saat permasalahan anak mulai diakseskan kepada sakti peksos di LPPA Jawa barat. Sakti peksos juga memberikan edukasi selama proses pendampingan yang dilakukan ketika sakti peksos bekerja dari rumah melalui chat WhatsApp (WA). Sakti peksos pada permasalahan anak korban tindak kekerasan seksual memberikan edukasi kepada anak dan orangtua anak agar hak-hak anak tetap terlindungi. Pemberian informasi dilakukan karena minimnya pengetahuan orangtua mengenai cara melaporkan permasalahan anak kepada polisi. Sakti peksos juga memberikan informasi kepada orangtua anak mengenai pengasuhan yang tepat bagi anak dan meminta agar lebih meluangkan dan memperhatikan anak. Sakti peksos juga mengkomunikasikan hasil konseling yang dilakukan oleh psikolog kepada orangtua. Sakti peksos memberikan sex education kepada anak, agar kedepannya permasalahan yang sama tidak terulang lagi dan anak mengetahui bahwa hal tersebut bukanlah bentuk kasih sayang.

Sakti peksos dalam menjalankan peran edukator pada permasalahan anak korban tindak kekerasan dalam rumah tangga yang melalui jalur hukum dilakukan pada saat permasalahan anak mulai diakseskan kepada sakti peksos yang pada saat itu sedang bekerja dari rumah. Pemberian edukasi dilakukan ketika sakti peksos visit ke rumah anak dan secara daring. Sakti peksos menjalankan peran edukator juga pada permasalahan anak korban tindak kekerasan dalam rumah tangga yang tidak melalui jalur hukum, pemberian edukasian dilakuakan ketika pertama kali ibu dari anak menghubungi sakti peksos. Pengedukasian terhadap permasalahan anak korban tindak kekerasan dalam rumah tangga yang melalui jalur hukum diberikan kepada keluarga besar anak. Pemberian edukasi ini berkaitan dengan pola asuh yang tepat bagi anak dan berkaitan dengan masa tumbuh kembang anak. Sakti peksos memberikan edukasi kepada keluarga besar anak, agar anak untuk sementara 
waktu dirawat oleh keluarga besar. Pemberian edukasi pada permasalahan anak yang menjadi korban tindak kekerasan yang tidak melalui jalur hukum diberikan kepada orang tua dan anak. Perlunya orangtua diberikan informasi, dikarenakan orangtua tidak memahami informasi yang dibutuhkan dan juga mengenai dukungan psikososial agar tidak melampiaskan emosi pada anak. Anak juga diberikan dukungan psikososial.

Sakti peksos dalam menjalankan peran edukator dilakukan pada permasalahan anak terlantar, korban tindak kekerasan seksual, anak korban tindak kekerasan dalam rumah tangga dan anak korban penjambretan. Tidak semua sakti peksos menjalankan peran edukator, salah satu sakti peksos tidak menjalankan peran edukator. Sakti peksos dalam menjalankan perannya sebagai edukator mengalami hambatan-hambatan seperti cara penyampaian informasi yang ditakutkan kurang tepat, peyampaian informasi yang dilakukan secara daring dan sulitnya mengumpulkan massa untuk mengedukasi masyarakat sekitar, mengenai permasalahan yang dialami oleh anak. salah satu sakti peksos tidak menjalankan peran edukator, dikarenakan kurang memahami informasi yang harus diberikan kepada anak dan keluarga.

Berdasarkan hasil penelitian, permasalahan yang dialami oleh sakti peksos yakni, adanya sakti peksos yang tidak menjalankan peran edukator pada permasalahan anak terlantar, dikarenakan kurang memahami informasi yang perlu diberikan kepada orangtua dan anak. Sakti peksos juga tidak melakukan Temu Penguatan Anak dan Keluarga (TEPAK) sebagai bentuk edukasi pada masa pandemi dan sementara waktu edukasi diberikan dengan dukungan psikososial pada keluarga dan anak, namun tidak semua sakti peksos memberikan edukasi melalui dukungan psikososial. Permasalahan ini dikarenakan sakti peksos tidak memiliki latar belakang pendidikan pekerjaan sosial.

Permasalahan sakti peksos dalam menjalankan peran advokasi juga terkait dengan sulitnya mengkomunikasikan informasi yang dibutuhkan oleh keluarga dan anak. Menurut Zastrow (2017) pekerja sosial harus mampu mengkomunikasikan segala informasi dengan baik, sehingga dapat dipahami oleh klien. Namun tidak semua sakti peksos mengalami hambatan ketika menjalankan peran edukator, hal ini terlihat dari sakti peksos yang memberikan edukasi dengan cara memberikan dukungan psikososial dan mampu menyampaikan informasi dengan baik kepada anak dan keluarga. Sakti peksos dalam menyampaikan informasi dapat mengkomunikasikan dengan memberi contoh, ilustrasi dan pemberian logika berpikir.

\section{KESIMPULAN}

Peran satuan bakti pekerja sosial (sakti peksos) dalam memberikan perlindungan sosial kepada anak yang 
terekena pandemi covid-19 di Kota Bandung dilakukan oleh empat orang sakti peksos. Adapun permasalahan anak yang terkena dampak pandemi covid-19 di Kota Bandung bukan merupakan dampak langsung dari pandemi covid-19. Permasalahan anak yang terkena dampak pandemi covid-19 di Kota Bandumg merupakan dampak tidak langsung dari adanya pandemi covid-19 di Indonesia yang menyerang anak-anak.

Dampak tidak langsung yang terjadi pada anak yang kemudian diakseskan kepada sakti peksos ialah permasalahan anak terlantar, anak korban tindak kekerasan dalam rumah tangga, anak korban penjambretan dan anak korban tindak kekerasan. Permasalahanpermasalahan ini kemudian diakseskan kepada sakti peksos untuk ditangani, adapun pihak yang mengakses berasal dari laporan masyarakat kepada Dinas Sosial dan Penanggulangan Kemiskinan Kota Bandung, Supervisor satuan bakti pekerja sosial Jawa Barat, Polisi Resor Kota Besar Kota Bandung, dan Pusat Pelayanan Terpadu Pemberdayaan Perempuan dan Anak (P2TP2A) Kota Bandung.

Hasil penelitian menunjukkan bahwa sakti peksos dalam memberikan perlindungan sosial kepada anak yang terkena dampak pandemi covid-19 menjalankan peran sebagai advokator, broker, dan edukator.

Sakti peksos menjalankan peran sebagai advokator guna mencegah terulangnya pelanggaran terhadap anak ke depannya dan agar hak-hak anak terlindungi. Sakti peksos dalam mengadvokasikan hak-hak anak, dilakukan setelah asesmen dan kemudian dilakukan pengadvokasian dengan memberikan pendampingan selama proses hukum, mengadvokasikan pada masyarakat dan juga berbicara atas nama klien.

Sakti peksos menjalankan peran sebagai broker dikarenakan kepentingan yang terbaik bagi anak untuk diakseskan kepada sistem sumber dan ketidaktahuan klien untuk mengakses sistem sumber. Sakti peksos menghubungkan anak kepada beberapa lembaga pelayanan yang menyediakan bantuan yang dibutuhkan dan juga kepada jejaring-jejaring yang menyediakan keperluan anak, seperti psikolog di P2TP2A, jejaring organiasi sosial dan yayasan.

Sakti peksos perlu menjalanakan peran edukator dikarenakan minimnya informasi yang diketahui oleh anak dan keluarga dan juga tidak memahami informasi. Sakti peksos lebih banyak memberikan infromasi yang dibutuhkan dengan cara mengkomunikasikan, sharing dan dukungan psikososial kepada anak dan keluarga.

Hasil penelitian menunjukkan hambatan yang dialami oleh sakti peksos dalam menjalankan peran broker terkait dengan mencari sistem sumber yang dapat menyediakan bantuan bagi anak. Namun, sakti peksos dapat menemukan sistem sumber yang dibutuhkan, walau memakan 
waktu sedikit lebih lama. Sakti peksos dalam menjalankan peran advokator mengalami hambatan terkait SOP (Standard Operational Procedure), ruang gerak terbatas dan pelaksanaan pelayanan daring.

Sakti peksos dalam menjalankan peran advokator mengalami hambatan yang umumnya terjadi ketika pandemi. Peran edukator merupakan peran yang pelaksanaannya mengalami banyak hambatan. Sakti peksos pada masa pandemi, tidak melakukan Temu Penguatan Anak dan Keluarga (TEPAK). Pemberian edukasi dilakukan dengan pemberian dukungan psikososial. Namun beberapa sakti peksos tidak memberikan edukasi dengan pemberian dukungan psikososial. Beberapa sakti peksos juga mengalami hambatan dalam menyampaikan informasi yang dibutuhkan oleh anak dan keluarga.

\section{DAFTAR PUSTAKA}

Abu Huraerah. 2012. Kekerasan Terhadap Anak III. Bandung: Nuansa Cindekia.

Adi Fahrudin. 2010. "Advokasi Pekerja Sosial.

https://www.researchgate.net/publu cation/308985836_ADVOKASI_P EKERJAAN_SOSIAL (Diakses tanggal 12 Juli 2020 pukul 11.34)

Buku Pedoman Satuan Bakti Pekerja Sosial. 2016. Direktorat Kesejahteraan Sosial RI. covid.go.id (Diakses tanggal 20 Mei 2020 pukul 10.13) https://kekerasan.kemenpppa.go.id/ringka san (Diakses tanggal 22 Agustus 2020 pukul 19.47)

ILO. 2020. "Covid-19 Ad the World of Work: Impact and Policy Response"

https://www.ilo.org/wcmsp5/groups /public/-dgreports/dcomm/documents/briefingnote/wc ms_738753.pdf (Diakses tanggal 5 Juni 2020 pukul 5 Juni 2020)

Komnas Perempuan. 2019. Siaran Pers Catatan Tahunan (CATAHU) 2019. https://www.komnasperempuan.go.i d/read-news-siaran-pers-catatantahunan-catahu-komnasperempuan-2019 (Diakses tanggal 2 Desember 2019 pukul 22.35)

United Nations Childern's Fund (UNICEF). 2020. Situasi Anak di Indonesia-Tren, Peluang dan Tantangan Dalam Memenuhi HakHak Anak. Jakarta: UNICEF Indonesia

Wawan Mas'udi \& Poppy. S Winanti. 2020. Tata Kelola Penanganan Covid-19 di Indonesia: Kajian Awal. Yogyakarta: Gadjah Mada University Press.

Webb, Nancy Boyd. 2011. Social Work Practice with Childern. New York: The Guilford Press

www.who.int (Diakses tanggal $20 \mathrm{Mei}$ 2020 pukul 11.15)

Zastrow, Charles. 2017. Introduction to Social Work and Social Welfare Empowering People, Twelfth Edition. Canada: Nelson Education, ltd. 